\title{
Krokinobacter gen. nov., with three novel species, in the family Flavobacteriaceae
}

Correspondence

Shams Tabrez Khan

shams-tabrez-khan@nite.go.jp

\author{
Shams Tabrez Khan, Yasuyoshi Nakagawa and Shigeaki Harayama \\ Biological Resource Center (NBRC), National Institute of Technology and Evaluation (NITE), \\ 2-5-8, Kazusa-kamatari, Kisarazu, Chiba 292-0818, Japan
}

\begin{abstract}
Five strains belonging to the family Flavobacteriaceae were isolated from marine-sediment samples collected in Sagami and Tokyo bays on the Pacific coastline of Japan. The five isolates formed a coherent and novel genus-level lineage within the family Flavobacteriaceae. The most closely related species with a validly published name was Cellulophaga lytica. The five isolates were rod-shaped, Gram-negative, aerobic, catalase- and oxidase-positive, flexirubin-negative and yellow-pigmented. The dominant fatty acids were branched or hydroxy acids, i.e. i- $\mathrm{C}_{15: 0}$, i- $\mathrm{C}_{15: 1}$ and $\mathrm{i}-\mathrm{C}_{17: 0} 3-\mathrm{OH}$. These strains degraded gelatin, casein, DNA and Tween 80 . The $\mathrm{G}+\mathrm{C}$ content of their DNAs ranged between 33 and 39 mol\%. Although analysis of the $16 \mathrm{~S}$ rRNA gene sequence similarity divided these strains into two subgroups with a $2.3 \%$ sequence difference, the results of DNA-DNA hybridization indicated the grouping of these strains into three distinct species. On the basis of phenotypic and genotypic analyses, the novel genus Krokinobacter is proposed, with Krokinobacter genikus sp. nov., containing three of the strains, as the type species. The type strain is $\operatorname{Cos}^{-13^{\top}}\left(=\right.$ NBRC $100811^{\top}=$ CIP $\left.108744^{\top}\right)$. The names Krokinobacter eikastus sp. nov. (type strain PMA-26 $6^{\top}=$ NBRC $\left.100814^{\top}=\mathrm{CIP} 108743^{\top}\right)$ and Krokinobacter diaphorus sp. nov. (type strain MSKK-32 ${ }^{\top}=$ NBRC $100817^{\top}=$ CIP $108745^{\top}$ ) are proposed for the other two isolates.
\end{abstract}

Flavobacteria play an important role in the uptake and degradation of dissolved and particulate organic matter (Kirchman, 2002), and the ability to degrade macromolecules such as casein, starch, agar, carrageenan and DNA is a good diagnostic marker for members of the family Flavobacteriaceae. The family was first proposed by Jooste (1985) and the name was validly published in 1992 (Reichenbach, 1992). Since then, a number of novel genera have been added with subsequent emended descriptions of the family (Bernardet et al., 1996, 2002). According to the new descriptions, members of the Flavobacteriaceae are Gram-negative, non-spore-forming, short to moderately long rods and are unable to degrade crystalline cellulose. Their major cellular fatty acids are branched or hydroxy fatty acids (high levels of $\mathrm{i}-\mathrm{C}_{15: 0}, \mathrm{i}-\mathrm{C}_{15: 1}$ and $\mathrm{i}-\mathrm{C}_{17: 0} 3-\mathrm{OH}$ ) and MK-6 is the only quinone found. Although their DNA G + C content has been reported to be in the range $27-44 \mathrm{~mol} \%$ (Bernardet et al., 2002), the value for one novel member of the Flavobacteriaceae, Robiginitalea biformata, was found to be $55-56 \mathrm{~mol} \%$ (Cho \& Giovannoni, 2004). In this paper, we report the characterization of five strains isolated from

Published online ahead of print on 7 October 2005 as DOI 10.1099/ ijs.0.63841-0.

The GenBank/EMBL/DDBJ accession numbers for the 16S rRNA gene sequences of strains Cos-12, Cos-13 $3^{\top}$, CKS-39, PMA-26 ${ }^{\top}$ and MSKK-32 ${ }^{\top}$ are AB198085-AB198089, respectively. marine-sediment samples. On the basis of the results of polyphasic analyses, we propose the classification of these strains as members of a novel genus of the family Flavobacteriaceae.

Five strains, Cos-12 (=NBRC 100815), Cos- $13^{\mathrm{T}}(=$ NBRC $\left.100811^{\mathrm{T}}=\mathrm{CIP} 108744^{\mathrm{T}}\right), \mathrm{PMA}-26^{\mathrm{T}}\left(=\mathrm{NBRC} 100814^{\mathrm{T}}=\mathrm{CIP}\right.$ $\left.108743^{\mathrm{T}}\right), \operatorname{MSKK}-32^{\mathrm{T}}\left(=\mathrm{NBRC} 100817^{\mathrm{T}}=\mathrm{CIP} 108745^{\mathrm{T}}\right)$ and CKS-39 (=NBRC 100806), were isolated from marinesediment samples collected from the Pacific coastline of Japan. Strains Cos-12 and Cos- $13^{\mathrm{T}}$ were isolated from the city of Odawara while the other three strains were from Kisarazu. Cell morphology was examined under an Olympus light microscope (model CX41LF). A flexirubin-type pigment was detected in the bathochromatic shift test used with $20 \%(\mathrm{w} / \mathrm{v}) \mathrm{KOH}$ as described by McCammon \& Bowman (2000). Carotenoids in acetone extracts were detected spectroscopically by using a Shimadzu UV-visible spectrophotometer (model UV-1650PC). Denitrification, indole production, acid production from glucose, urease production, aesculin hydrolysis and gelatin liquefaction were tested for with API 20 NE strips (bioMérieux) according to the manufacturer's instructions (except that artificial sea water was used as the basal medium). Catalase activity was tested for by the addition of $3 \%(\mathrm{v} / \mathrm{v}) \mathrm{H}_{2} \mathrm{O}_{2}$ to bacterial colonies: the formation of bubbles (oxygen gas) was taken as a positive result. For the oxidase test, cells 
collected from fresh cultures were spread on cytochrome oxidase strips (Nissui Pharmaceutical): a colour change (to blue) was taken as a positive result. Liquefaction of starch, casein, chitin, cellulose (No. 1 filter paper; Whatman), carboxymethyl cellulose (high viscosity; Sigma) and DNA was examined as described by Cowan \& Steel (1993). Depolymerization of agar and carrageenan (Type I; Sigma) was examined by simply growing the strains on the plates containing Bacto marine broth 2216 (Difco) and $1.5 \%$ each polysaccharide as the solidifying agent. For determining the optimal growth temperature, strains were cultivated in marine broth at $4,10,20,30$ and $40^{\circ} \mathrm{C}$. The ability to grow at different salt concentrations was tested for by growing the strains in 1/5-strength LB broth [2 g Bacto tryptone (Difco) and $1 \mathrm{~g}$ Bacto yeast extract (Difco) in $1 \mathrm{l}$ water supplemented with $1,1 \cdot 5,3,5,7,10$ or $15 \% \mathrm{NaCl}]$.

The ability to utilize 95 different carbon sources was determined by using Biolog GN2 microplates in combination with a Biolog MicroStation plate, according to Rüger \& Krambeck (1994). Cellular fatty acid compositions were analysed either by using the Sherlock Microbial Identification System (MIDI) or by means of GC/MS with an Agilent 6890 GC system fitted with an Agilent Ultra2 column. DNA for the sequencing of the 16S rRNA gene was extracted by using InstaGene Matrix (Bio-Rad); 16S rRNA gene fragments corresponding to positions 8-1492 in the Escherichia coli 16S rRNA gene (Brosius et al., 1978) were amplified with a pair of universal primers, $27 \mathrm{f}$ and $1492 \mathrm{r}$, as described by Hiraishi et al. (1994). Amplicons were directly sequenced using the BigDye Terminator v1.1 cycle sequencing kit and an ABI PRISM 3100 Genetic Analyzer (Applied Biosystems). Sequences were edited and assembled using the ATGC program (Genetyx). Published 16S rRNA gene sequences were downloaded from the DNA Database of Japan (DDBJ) and then aligned by using CLUSTAL X (Thompson et al., 1997). The neighbour-joining algorithm of Saitou \& Nei (1987) was used to infer phylogenetic relationships, and the robustness of the tree topology was evaluated by bootstrap resampling analysis (Felsenstein, 1985) of 1000 replicates. For determination of the DNA G $+\mathrm{C}$ content, genomic DNA was extracted from cells grown to late exponential phase either on marine agar 2216 (Difco) or in marine broth, according to the protocol of Minamisawa (1990). The $\mathrm{G}+\mathrm{C}$ content was determined by HPLC according to the method of Mesbah et al. (1989). A fluorometric hybridization method was used for quantitative DNA-DNA hybridization, as described by Ezaki et al. (1989). Hybridization was carried out in $25 \%$ formamide at $49^{\circ} \mathrm{C}$.

Cells of strains Cos- 12 , Cos- $13^{\mathrm{T}}, \mathrm{PMA}-26^{\mathrm{T}}, \mathrm{MSKK}-32^{\mathrm{T}}$ and CKS-39 were all Gram-negative, flexirubin-negative rods, $0 \cdot 5-0 \cdot 7 \mu \mathrm{m}$ in width and $2 \cdot 5-4 \cdot 0 \mu \mathrm{m}$ in length. Three-dayold colonies on marine agar were slightly convex, lemonyellow in colour and 1-2 $\mathrm{mm}$ in diameter, with regular to irregular edges. The lemon-yellow colour of the colonies was due to carotenoids, as was evident from the absorption spectra of acetone extracts (data not shown). The optimal temperature for growth was in the range $15-25^{\circ} \mathrm{C}$, and very weak growth, or no growth, was observed at temperatures below $10^{\circ} \mathrm{C}$ and above $30^{\circ} \mathrm{C}$. Growth was inhibited by high $(10 \%)$ or low $(1 \cdot 5 \%) \mathrm{NaCl}$ concentrations.

All of the strains tested were positive for catalase, oxidase, $\beta$ galactosidase and $\beta$-glucosidase and for hydrolysis of gelatin, casein, DNA and Tweens 40, 60 and 80, but they were negative for urease, arginine dihydrolase, acid production from glucose, indole production and for hydrolysis of cellulose, starch, chitin and carboxymethyl cellulose (except for Cos-12 and Cos-13, which were positive for the hydrolysis of carboxymethyl cellulose). Utilization of various carbon sources was examined using Biolog GN2 plates: of the 95 different carbon sources tested, 21 carbon sources, namely dextrin, cellobiose, D-fructose, gentiobiose, $\alpha$-D-glucose, lactose, lactulose, maltose, methyl $\beta$-D-glucoside, raffinose,

Table 1. Whole-cell fatty acid profiles of strains representing different species of Krokinobacter and C. lytica, the closest phylogenetic relative

Strains/species: 1, K. genikus Cos- $13^{\mathrm{T}} ; 2, K$. eikastus PMA- $26^{\mathrm{T}}$; 3, K. diaphorus MSKK-32 $2^{\mathrm{T}} ; 4$, C. lytica. Data for C. lytica are adapted from Bowman (2000). tr, Trace amount.

\begin{tabular}{|c|c|c|c|c|}
\hline Fatty acid & 1 & 2 & 3 & 4 \\
\hline $\mathrm{i}-\mathrm{C}_{13: 0}$ & $\operatorname{tr}$ & $\operatorname{tr}$ & - & - \\
\hline $\mathrm{i}-\mathrm{C}_{14: 0}$ & 2 & $\operatorname{tr}$ & 1 & - \\
\hline $\mathrm{i}-\mathrm{C}_{15: 0}$ & 20 & 13 & 22 & 19 \\
\hline $\mathrm{a}-\mathrm{C}_{15: 0}$ & 6 & 5 & 8 & 1 \\
\hline $\mathrm{i}-\mathrm{C}_{15: 1}$ & 25 & 26 & 15 & 10 \\
\hline$a-C_{15: 1}$ & 4 & 6 & 3 & - \\
\hline $\mathrm{C}_{15: 0}$ & - & - & - & 9 \\
\hline $\mathrm{C}_{15: 1} \omega 6 c$ & - & - & - & 2 \\
\hline $\mathrm{i}-\mathrm{C}_{16: 0}$ & 3 & 2 & 4 & $\operatorname{tr}$ \\
\hline $\mathrm{i}-\mathrm{C}_{16: 1}$ & 2 & $\operatorname{tr}$ & 3 & 1 \\
\hline $\mathrm{C}_{16: 0}$ & - & $\operatorname{tr}$ & $\operatorname{tr}$ & 2 \\
\hline Summed feature $A^{*}$ & 8 & 11 & 5 & 9 \\
\hline $\mathrm{i}-\mathrm{C}_{17: 1} \omega 7 c$ & - & - & - & 5 \\
\hline$a-C_{17: 1} \omega 9 c$ & - & - & - & - \\
\hline $\mathrm{C}_{17: 1} \omega 8 c$ & - & - & - & - \\
\hline $\mathrm{C}_{17: 1} \omega 6 c$ & $\operatorname{tr}$ & $\operatorname{tr}$ & $\operatorname{tr}$ & $\operatorname{tr}$ \\
\hline $\mathrm{i}-\mathrm{C}_{14: 0} 3-\mathrm{OH}$ & $\operatorname{tr}$ & $\operatorname{tr}$ & $\operatorname{tr}$ & - \\
\hline $\mathrm{C}_{15: 0} 2-\mathrm{OH}$ & 1 & 1 & 2 & - \\
\hline $\mathrm{i}-\mathrm{C}_{15: 0} 3-\mathrm{OH}$ & 3 & 3 & 2 & 6 \\
\hline $\mathrm{C}_{15: 0} 3-\mathrm{OH}$ & - & $\operatorname{tr}$ & $\operatorname{tr}$ & $\operatorname{tr}$ \\
\hline $\mathrm{i}-\mathrm{C}_{16: 0} 3-\mathrm{OH}$ & 12 & 5 & 6 & 5 \\
\hline $\mathrm{C}_{16: 0} 3-\mathrm{OH}$ & $\operatorname{tr}$ & 1 & - & $\operatorname{tr}$ \\
\hline $\mathrm{i}-\mathrm{C}_{17: 0} 3-\mathrm{OH}$ & 6 & 10 & 10 & 20 \\
\hline $\mathrm{C}_{17: 0} 2-\mathrm{OH}$ & 3 & 3 & 6 & - \\
\hline $\mathrm{C}_{17: 0} 3-\mathrm{OH}$ & - & - & $\operatorname{tr}$ & - \\
\hline $\mathrm{C}_{20: 4} \omega 6 c \dagger$ & - & 5 & 8 & - \\
\hline
\end{tabular}

${ }^{*}$ Summed feature A contains $\mathrm{C}_{16: 1} \omega 7 c$ and/or i- $\mathrm{C}_{15: 0}$ 12-OH.

$\dagger$ The presence of $\mathrm{C}_{20: 4} \omega 6 c$ (arachidonic acid) was confirmed by GC/MS. 


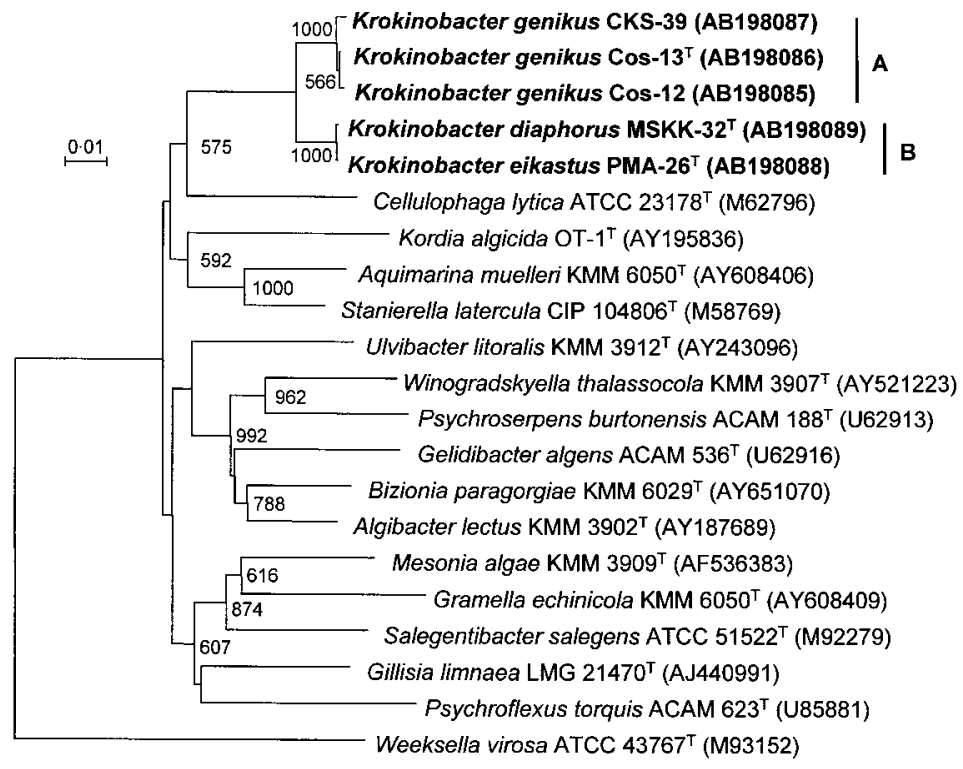

Fig. 1. Phylogenetic relationship of Krokinobacter with other genera of the family Flavobacteriaceae on the basis of $16 \mathrm{~S}$ rRNA gene sequence comparisons. The tree was generated by the neighbour-joining method; bootstrap values indicated at branches were calculated from 1000 resamplings. Bootstrap values lower than 500 are not shown. Bar, 0.01 $K_{\text {nuc }}$.

trehalose, sucrose, turanose, glycine, aspartic acid, glutamic acid, glycyl-L-aspartic acid, proline, threonine, uridine and ornithine, were utilized by all strains. In addition to the above-mentioned carbon sources, mannose and serine were utilized by Cos- 12 and Cos- $13^{\mathrm{T}}$, melibiose by Cos- 12 , Cos$13^{\mathrm{T}}$ and PMA- $26^{\mathrm{T}}$, alanine, succinate and succinamide by CKS-39 and MSKK- $32^{\mathrm{T}}$, acetic acid by Cos- $12, \operatorname{Cos}-13^{\mathrm{T}}$ and CKS-39 and mannitol by PMA- $26^{\mathrm{T}}$.

Like all other members of the family Flavobacteriaceae, the isolates contained $\mathrm{i}-\mathrm{C}_{15: 0}, \mathrm{i}-\mathrm{C}_{15: 1}$ and $\mathrm{i}-\mathrm{C}_{17: 0} 3-\mathrm{OH}$ as their major fatty acids (Table 1). The fatty acid profiles of the isolates were different from that of Cellulophaga lytica (the closest species with a validly published name: see below), which contained $\mathrm{i}-\mathrm{C}_{17: 1} \omega 7 \mathrm{c}$ and $\mathrm{C}_{15: 0}$. The fatty acid

Table 2. Levels of DNA-DNA hybridization and 16S rRNA gene sequence similarity between different strains of Krokinobacter

Similarities (\%) of the 16S rRNA gene sequences are shown above the diagonal line from upper left to lower right, while DNA-DNA reassociation values (\%) are shown below the diagonal line. Subclusters A and B were revealed by the phylogenetic analysis shown in Fig. 1.

\begin{tabular}{|c|c|c|c|c|c|}
\hline \multirow[t]{2}{*}{ Strain } & \multicolumn{3}{|c|}{ Subcluster A } & \multicolumn{2}{|c|}{ Subcluster B } \\
\hline & Cos- 12 & $\operatorname{Cos}-13^{T}$ & CKS-39 & PMA-26 ${ }^{\mathrm{T}}$ & MSKK-32 ${ }^{\mathrm{T}}$ \\
\hline Cos- 12 & 100 & $99 \cdot 8$ & $99 \cdot 6$ & $97 \cdot 6$ & $97 \cdot 6$ \\
\hline $\operatorname{Cos}-13^{\mathrm{T}}$ & 87 & 100 & $99 \cdot 5$ & $97 \cdot 6$ & $97 \cdot 6$ \\
\hline CKS-39 & 78 & 84 & 100 & $97 \cdot 7$ & $97 \cdot 7$ \\
\hline PMA- $26^{\mathrm{T}}$ & 35 & 38 & 40 & 100 & $99 \cdot 9$ \\
\hline MSKK- $32^{\mathrm{T}}$ & 14 & 12 & 16 & 30 & 100 \\
\hline
\end{tabular}

compositions of these isolates were also different from each other.

Comparison of almost-complete 16S rRNA gene sequences (1446 bp) of the isolates with public databases showed the closest relative to be an unclassified Cytophaga-like strain (accession no. AF427479) with a similarity of $93 \%$. A phylogenetic analysis with type strains of the family

Table 3. Physiological and biochemical characteristics that differentiate Krokinobacter gen. nov. from related genera of the family Flavobacteriaceae

Genera: 1, Krokinobacter gen. nov. $\left(\operatorname{Cos}-13^{\mathrm{T}}\right) ; 2$, Cellulophaga; 3, Psychroserpens; 4, Algibacter; 5, Psychroflexus; 6, Salegentibacter. Data for genera other than Krokinobacter are from McCammon \& Bowman (2000), Bowman et al. (1997, 1998), Johansen et al. (1999) and Nedashkovskaya et al. (2004). -, Negative; +, positive; V, variable; NK, not known.

\begin{tabular}{|lcccccc|}
\hline Characteristic & $\mathbf{1}$ & $\mathbf{2}$ & $\mathbf{3}$ & $\mathbf{4}$ & $\mathbf{5}$ & $\mathbf{6}$ \\
\hline $\begin{array}{l}\text { Colony colour } \\
\text { Depolymerization of: }\end{array}$ & $\mathrm{Y}$ & $\mathrm{O}-\mathrm{Y}$ & $\mathrm{Y}$ & $\mathrm{O}$ & $\mathrm{O}$ & $\mathrm{Y}$ \\
$\quad$ Agar & - & + & - & + & - & - \\
$\quad$ Casein & + & $\mathrm{V}$ & + & - & - & - \\
$\quad$ Starch & - & + & - & + & + & + \\
$\quad$ DNA & + & + & - & - & + & + \\
Nitrate reduction & - & $\mathrm{V}$ & - & $\mathrm{NK}$ & - & + \\
Growth in > $>$ \% & - & - & - & - & $\mathrm{V}$ & + \\
salts & & & & & & \\
DNA G+C content & $33-39$ & $33-38$ & $27-29$ & $31-33$ & $32-36$ & $37-38$ \\
$\quad(\mathrm{~mol} \%)$ & & & & & & \\
\hline
\end{tabular}

${ }^{\star} \mathrm{O}$, Orange; Y, yellow. 
Flavobacteriaceae showed that these five strains form a distinct monophyletic cluster, with C. lytica as the closest species with a validly published name (Fig. 1). The sequence similarity between the 16S rRNA gene sequences of these five isolates and that of C. lytica was in the range 91.2$91.7 \%$. This novel clade was further divided into two subclusters, with Cos-12, Cos- $13^{\mathrm{T}}$ and CKS-39 in subcluster A and MSKK- $32^{\mathrm{T}}$ and PMA-28 in subcluster B (Fig. 1). Strains within the same subcluster shared a high level of sequence similarity $(>99 \cdot 5 \%)$, whereas levels of similarity between strains from different subclusters were lower $(97 \cdot 6-97 \cdot 9 \%)$ (Table 2). The low level of similarity between the 16S rRNA gene sequences of these isolates and those of published sequences indicated that these five isolates should be classified as members of a novel genus of the family Flavobacteriaceae. This conclusion was also supported by the differences in phenotypic characteristics, as summarized in Table 3.

The DNA G $+\mathrm{C}$ content of all the strains was in the range 37-39 mol\%, except for strain MSKK- $32^{\mathrm{T}}$, which had a $\mathrm{G}+\mathrm{C}$ content of $33 \mathrm{~mol} \%$. All the values fell within a range typical of the $\mathrm{G}+\mathrm{C}$ content of members of the Flavobacteriaceae.

The DNA-DNA reassociation values of the strains within subcluster A were at least $70 \%$ (Table 2). Cos- $13^{\mathrm{T}}$ and Cos12 showed a DNA relatedness of $87 \%$, while strains CKS-39 and Cos $-13^{\mathrm{T}}$ showed $84 \%$ relatedness. Unlike the strains in subcluster $\mathrm{A}$, two strains of subcluster B, PMA $-26^{\mathrm{T}}$ and MSKK- $32^{\mathrm{T}}$, showed a very low level of DNA-DNA relatedness $(30 \%)$. These two strains also showed low levels of DNA relatedness (12-38\%) with the strains of subcluster A. The results shown in Table 2 strongly suggested that the strains of subcluster A constitute one species and that strains PMA- $26^{\mathrm{T}}$ and MSKK- $32^{\mathrm{T}}$ (subcluster B), despite sharing a very high level of $16 \mathrm{~S}$ rRNA gene sequence similarity, belong to different species. This conclusion was also supported by other properties such as the carbon sources utilized and the cellular fatty acid compositions (Tables 1 and 3). Thus, for these strains, we propose a novel genus, Krokinobacter gen. nov., that includes three novel species: the first species, Krokinobacter genikus sp. nov., includes strains in subcluster A, Cos-13 ${ }^{\mathrm{T}}$, Cos-12 and CKS-39, while Krokinobacter eikastus sp. nov. and Krokinobacter diaphorus sp. nov. are represented by PMA- $26^{\mathrm{T}}$ and MSKK $-32^{\mathrm{T}}$, respectively. Several biochemical characteristics were useful for differentiating these Krokinobacter species (Table 4). K. genikus can be differentiated from the other two species by its ability to utilize acetic acid, and by the absence of arachidonic acid $\left(\mathrm{C}_{20: 4} \omega 6 c\right)$ in its fatty acids. Although the synthesis of polyunsaturated fatty acids in bacteria is unusual, a group of strains belonging to the family Flavobacteriaceae have been shown to synthesize arachidonic acid (Bowman et al., 1998). The species K. eikastus can be differentiated from other species by its utilization of mannitol, while $K$. diaphorus differs from the other species in having low levels of DNA-DNA relatedness to, and a lower $\mathrm{G}+\mathrm{C}$ content than, other species.
Table 4. Differentiating characteristics for Krokinobacter species

Strains: $1, K$. genikus $\operatorname{Cos}-13^{\mathrm{T}} ; 2, K$. eikastus PMA-26 ${ }^{\mathrm{T}} ; 3, K$. diaphorus MSKK- $32^{\mathrm{T}}$.

\begin{tabular}{|lccc|}
\hline Characteristic & $\mathbf{1}$ & $\mathbf{2}$ & $\mathbf{3}$ \\
\hline Utilization of: & - & + & - \\
$\quad$ Mannitol & + & - & - \\
$\quad$ Acetic acid & 0 & 5 & 8 \\
Arachidonic acid content (\% of total & & & \\
fatty acids) & 37 & 38 & 33 \\
DNA G+C content (mol\%) & & & \\
\hline
\end{tabular}

\section{Description of Krokinobacter gen. nov.}

Krokinobacter (Kro.ki'no.bac.ter. Gr. adj. krokinos yellow; N.L. masc. n. bacter from Gr. n. bakterion rod; N.L. masc. n. Krokinobacter a yellow, rod-like bacterium).

Gram-negative, aerobic and flexirubin-negative rods $0 \cdot 5$ $0 \cdot 7 \mu \mathrm{m}$ by $2 \cdot 5-4 \cdot 0 \mu \mathrm{m}$. Carotenoid-type pigments present. Positive for catalase and oxidase and for degradation of gelatin, casein and DNA. Negative for the following: degradation of agar, carrageenan, cellulose, chitin and starch, acid production from glucose, urease activity and nitrate reduction and denitrification. Utilizes dextrin, cellobiose, Dfructose, gentiobiose, $\alpha$-D-glucose, lactose, lactulose, maltose, methyl $\beta$-D-glucoside, raffinose, trehalose, sucrose, turanose, glycine, aspartic acid, glutamic acid, glycyl-Laspartic acid, proline, threonine, uridine and ornithine. Cannot utilize adonitol, arabitol, erythritol, fucose, galactose, inositol, mannose, melibiose, psicose, rhamnose, sorbitol, xylitol, pyruvate, succinate, aconitic acid, citric acid, formic acid, galactonic acid lactone, galacturonic acid, gluconic acid, glucosaminic acid, glucuronic acid, $\alpha-, \beta$ - and $\gamma$-hydroxybutyric acids, $p$-hydroxyphenylacetic acid, itaconic acid, $\alpha$-ketobutyric acid, $\alpha$-ketoglutaric acid, $\alpha$-ketovaleric acid, malonic acid, propionic acid, quinic acid, saccharic acid, sebacic acid, succinic acid, bromosuccinic acid, succinamic acid, glucuronamide, alaninamide, alanine, asparagine, glycyl L-glutamic acid, histidine, leucine, phenylalanine, pyroglutamic acid, serine, carnitine, aminobutyric acid, urocanic acid, inosine, thymidine, phenylethylamine, putrescine, aminoethanol, butanediol, glycerol, glycerol phosphate or glucose phosphate. No growth occurs at 10 or $0 \% \mathrm{NaCl}$. The major cellular fatty acids are $\mathrm{i}-\mathrm{C}_{15: 0}$, $\mathrm{i}$ $\mathrm{C}_{15: 1}, \mathrm{i}-\mathrm{C}_{17: 0} 3-\mathrm{OH}$ and $\mathrm{C}_{16: 1} \omega 7 c$ and/or i- $\mathrm{C}_{15: 0} 12-\mathrm{OH}$ (summed feature A: fatty acids that could not be separated by GC). The DNA G+C content is in the range 33-39 mol\%. The type species is Krokinobacter genikus.

\section{Description of Krokinobacter genikus sp. nov.}

Krokinobacter genikus (ge'ni.kus. N.L. masc. adj. genikus from Gr. masc. adj. genikos principal, typical).

The species displays the following properties in addition to those given in the genus description. Colonies on marine 
agar 2216 are yellow and slightly convex. Grows optimally at $20{ }^{\circ} \mathrm{C}$ and with $3 \%$ salts. Acetic acid is utilized, but mannitol is not utilized. No growth at 0 or $10 \% \mathrm{NaCl}$. Unlike other Krokinobacter species, the cellular fatty acids do not contain arachidonic acid. The DNA G $+\mathrm{C}$ content is $37-39 \mathrm{~mol} \%$.

The type strain is $\operatorname{Cos}-13^{\mathrm{T}}\left(=\mathrm{NBRC} 100811^{\mathrm{T}}=\mathrm{CIP} 108744^{\mathrm{T}}\right)$, isolated from marine sediment at Odawara, Japan. Strains Cos-12 ( = NBRC 100815) (isolated at Odawara) and CKS-39 (NBRC 100806) (isolated at Kisarazu) are reference strains.

\section{Description of Krokinobacter eikastus sp. nov.}

Krokinobacter eikastus (ei.kas'tus. N.L. masc. adj. eikastus from Gr. masc. adj. eikastos similar, comparable).

The species displays the following properties in addition to those given in the genus description. The optimal growth temperature is $20^{\circ} \mathrm{C}$ and the optimal salt concentration is $3 \%$. Colonies are slightly convex and yellowish on marine agar 2216. Mannitol is utilized, but acetate is not utilized. The cellular fatty acids include arachidonic acid. The DNA $\mathrm{G}+\mathrm{C}$ content is $38 \mathrm{~mol} \%$.

The type strain is PMA- $26^{\mathrm{T}}\left(=\mathrm{NBRC} 100814^{\mathrm{T}}=\mathrm{CIP}\right.$ $108743^{\mathrm{T}}$ ), isolated from marine sediment collected at Kisarazu, Japan.

\section{Description of Krokinobacter diaphorus sp. nov.}

Krokinobacter diaphorus (di.aph'or.us. N.L. masc. adj. diaphorus from Gr. masc. adj. diaphoros different, unlike).

The species displays the following properties in addition to those given in the genus description. Colonies on marine agar 2216 are slightly convex and yellowish. Grows optimally at $20{ }^{\circ} \mathrm{C}$ and with $3 \%$ salts. Neither acetic acid nor mannitol is utilized. The cellular fatty acids include arachidonic acid. The DNA G $+\mathrm{C}$ content is $33 \mathrm{~mol} \%$.

The type strain is MSKK $-32^{\mathrm{T}}\left(=\mathrm{NBRC} 100817^{\mathrm{T}}=\mathrm{CIP}\right.$ $\left.108745^{\mathrm{T}}\right)$, isolated from marine sediment at Kisarazu, Japan.

\section{Acknowledgements}

This work was supported by grant no. 04000182-0 from the New Energy Development Organization (NEDO).

\section{References}

Bernardet, J.-F., Segers, P., Vancanneyt, M., Berthe, F., Kersters, K. \& Vandamme, P. (1996). Cutting a Gordian knot: emended classification and description of the genus Flavobacterium, emended description of the family Flavobacteriaceae, and proposal of Flavobacterium hydatis nom. nov. (basonym, Cytophaga aquatilis Strohl and Tait 1978). Int J Syst Bacteriol 46, 128-148.

Bernardet, J.-F., Nakagawa, Y. \& Holmes, B. (2002). Proposed minimal standards for describing new taxa of the family Flavobacteriaceae and emended description of the family. Int J Syst Evol Microbiol 52, 1049-1070.
Bowman, J. P. (2000). Description of Cellulophaga algicola sp. nov., isolated from the surfaces of Antarctic algae, and reclassification of Cytophaga uliginosa (ZoBell and Upham 1944) Reichenbach 1989 as Cellulophaga uliginosa comb. nov. Int J Syst Evol Microbiol 50, 1861-1868.

Bowman, J. P., McCammon, S. A., Brown, J. L., Nichols, P. D. \& McMeekin, T. A. (1997). Psychroserpens burtonensis gen. nov., sp. nov., and Gelidibacter algens gen. nov., sp. nov., psychrophilic bacteria isolated from Antarctic lacustrine and sea ice habitats. Int J Syst Bacteriol 47, 670-677.

Bowman, J. P., McCammon, S. A., Lewis, T., Skerrat, J. H., Brown, J. L., Nichols, D. S. \& McMeekin, T. A. (1998). Psychroflexus torquis gen. nov., sp. nov., a psychrophilic species from Antarctic sea ice, and reclassification of Flavobacterium gondwanense (Dobson et al. 1993) as Psychroflexus gondwanense gen. nov., comb. nov. Microbiology 144, 1601-1609.

Brosius, J., Palmer, M. L., Kennedy, P. J. \& Noller, H. F. (1978). Complete nucleotide sequence of a $16 \mathrm{~S}$ ribosomal RNA gene from Escherichia coli. Proc Natl Acad Sci U S A 75, 4801-4805.

Cho, J.-C. \& Giovannoni, S. J. (2004). Robiginitalea bioformata gen. nov., sp. nov., a novel marine bacterium in the family Flavobacteriaceae with a higher $\mathrm{G}+\mathrm{C}$ content. Int J Syst Evol Microbiol 54, 1101-1106.

Cowan, S. T. \& Steel, K. J. (1993). Manual for the Identification of Medical Bacteria, 3rd edn. London: Cambridge University Press.

Ezaki, T., Hashimoto, Y. \& Yabuuchi, E. (1989). Fluorometric deoxyribonucleic acid-deoxyribonucleic acid hybridization in microdilution wells as an alternative to membrane filter hybridization in which radioisotopes are used to determine genetic relatedness among bacterial strains. Int J Syst Bacteriol 39, 224-229.

Felsenstein, J. (1985). Confidence limits on phylogenies: an approach using the bootstrap. Evolution 39, 783-791.

Hiraishi, A., Shin, Y. K., Ueda, Y. \& Sugiyama, J. (1994). Automated sequencing of PCR-amplified 16S rDNA on 'Hydrolink' gels. J Microbiol Methods 19, 145-154.

Johansen, J. E., Nielsen, P. \& Sjøholm, C. (1999). Description of Cellulophaga baltica gen. nov., sp. nov. and Cellulophaga fucicola gen. nov., sp. nov. and reclassification of [Cytophaga] lytica to Cellulophaga lytica gen. nov., comb. nov. Int J Syst Bacteriol 49, 1231-1240.

Jooste, P. J. (1985). The taxonomy and significance of FlavobacteriumCytophaga strains from dairy sources. $\mathrm{PhD}$ thesis, University of the Orange Free State, Bloemfontein, South Africa.

Kirchman, D. L. (2002). The ecology of Cytophaga-Flavobacteria in aquatic environments. FEMS Microbiol Ecol 39, 91-100.

McCammon, S. A. \& Bowman, J. P. (2000). Taxonomy of Antarctic Flavobacterium species: description of Flavobacterium gillisiae sp. nov., Flavobacterium tegetincola sp. nov. and Flavobacterium xanthum sp. nov., nom. rev. and reclassification of [Flavobacterium] salegens as Salegentibacter salegens gen. nov., comb. nov. Int J Syst Evol Microbiol 50, 1055-1063.

Mesbah, M., Premachandran, U. \& Whitman, W. B. (1989). Precise measurement of the $\mathrm{G}+\mathrm{C}$ content of deoxyribonucleic acid by high-performance liquid chromatography. Int J Syst Bacteriol 39, 159-167.

Minamisawa, K. (1990). Division of rhizobitoxine-producing and hydrogen-uptake positive strains of Bradyrhizobium japonicum by nifDKE sequence divergence. Plant Cell Physiol 31, 81-89.

Nedashkovskaya, O. I., Kim, S. B., Han, S. K. \& 7 other authors (2004). Algibacter lectus gen. nov., sp. nov., a novel member of the family Flavobacteriaceae isolated from green algae. Int J Syst Evol Microbiol 54, 1257-1261. 
Reichenbach, H. (1992). Flavobacteriaceae fam. nov. In Validation of the Publication of New Names and New Combinations Previously Effectively Published Outside the IJSB, List no. 41. Int J Syst Bacteriol 42, 327-329.

Rüger, H.-J. \& Krambeck, H.-J. (1994). Evaluation of the BIOLOG substrate metabolism system for classification of marine bacteria. Syst Appl Microbiol 17, 281-288.
Saitou, N. \& Nei, M. (1987). The neighbor-joining method: a new method for reconstructing phylogenetic trees. Mol Biol Evol 4, 406-425.

Thompson, J. D., Gibson, T. J., Plewniak, F., Jeanmougin, F. \& Higgins, D. G. (1997). The CLUSTAL_X windows interface: flexible strategies for multiple sequence alignment aided by quality analysis tools. Nucleic Acids Res 25, 4876-4882. 